\title{
RISK MANAGEMENT IN PUBLIC-PRIVATE PARTNERSHIP THROUGH MANAGEMENT CONTROL
}

\begin{abstract}
Division of risk between a public entity and a private partner is one on the most essential elements of public-private partnership. Improper risk allocation may cause difficulties in implementation of a given undertaking or even prevent its realisation. Proper risk management is significant to avoid such a state and management control is a mechanism facilitating it.

The aim of this article is to analyse management control in the scope of risk management in public-private partnership. Therefore, a research problem has been formulated which is to answer the question: is it possible to manage risk in PPP through management control? According to the research hypothesis, management control is an institution which may manage risk in PPP.

The article presents management control as a mechanism managing risk in PPP.
\end{abstract}

Keywords: risk, public-private partnership, management control

\section{Introduction}

Public-private partnership (PPP) is a cooperation of a public entity and a partner, in which the subject of the partnership is a joint implementation of an undertaking based on division of tasks and risk between the public entity and private partner.

This cooperation is aimed at obtaining benefits by both sides. Such partnership allows public bodies to implement public tasks, which are the needs of the society, with the participation of a private partner. Whereas the benefits to the private entities are the profits from the PPP projects. PPP was introduced into the Polish legal system by the Act of 28 July 2005 on public-private partnership [Journal of Laws No 169, item 1420]. This Act determines the rules and mode of a public entity and a private partner cooperation within PPP. The Act of 19 December 2008 on public-private partnership [Journal of Laws 2009 No 19, item 100] (APPP) introduced changes such as: elimination of unnecessary administrative burden and reduction of administrative constraints also regarding the subject and the content of the contract.

Risk division between a public entity and a private partner is an essential element of the PPP contracts. This division should be made in such a way as to assign particular risk to the entity which will cope with it most efficiently, i.e. level it out or limit its consequences. The following actions are necessary to do it effectively:

- risk identification,

- risk measurement and

- risk control.

All these actions comprise risk management, which consists in making decisions and implementing actions which lead to achieve a level of risk accepted by the partners. In practice, risk management is associated with the processes of risk assessment and control, whose aim is, among others, to create conditioning for further development. Management control is an example of risk management instrument which may be found in the Act on public finance [consolidated text, Journal of Laws of 2017 item 2077, later amended] (APF). Article 68(1) APF defines such a control as all actions taken to ensure the 
implementation of aims and tasks in a legal, efficient, cost-effective and timely manner. Whereas Art. 68(2)(7) APF indicates that the aim of the management control is in particular risk management.

Provisions of the APF are applied to public sector units and other entities in the scope in which they use or manage public funds. It means that management control may be applied in PPP implemented by the units on the national as well local government level.

\section{Risk}

As it has already been emphasised, a crucial element of partnership is risk, whose definition is not included in the APPP. This was a conscious and intended action of the legislator, who did not discharge PPP entities from defining risks and determining their division. The aim was not to limit this notion what would stiffen the PPP model.

Regulation of the Minister of Economy of 21 June 2006 on the risk involved in projects carried out through PPP [Journal of Laws No 125, item 868], issued on the basis of the Act on public-private partnership of 2005 [Act of 25 July 2005 on public-private partnership (Journal of Laws No 169, item 1420)], indicated 17 types of risk. Nowadays this regulation is not binding, although it is often referred to when risk is determined.

Risk has been the subject of many fields of science which tried to define it. Some described it as "an objective uncertainty of undesired occurrence" [Willet 1951, p. 6]. Others stated that risk is a possibility to materialise something unwanted, a negative consequence of a certain event [Rowe W.D. 1977, p. 24]. P.U. Kupsch distinguished two types of risk which combine to create a whole:

- formal,

- material risk.

Formal risk is a measurement of uncertainty of a given occurrence as a source. Material risk is a danger of loss [Kupsch 1975, p. 67]. Therefore, it may be assumed that risk is a factor, occurrence or impact which poses a threat to something or someone and which result may be a loss and probability is its shaping and value determinant.

When analysing the notion and types of risk connected with the implementation of PPP undertakings, it may be observed that there are many concepts of risk but it may be stated that risk is a state in which there is a possibility of negative deviation from the desired or expected result. Additionally, risk is an objective and measurable phenomenon [Kulesza, Bitner, Kozłowska 2006, p. 167].
According to the linguistic interpretation, risk describes a possibility that something will fail or an undertaking whose result is uncertain. It may also be a danger that something will happen differently than expected. Additionally, it is also a threat that damages burdening a person directly affected will occur, unless the contract or legal provisions oblige other person to cover the damages [Petrozolin-Skawrońska 1998, p. 1521].

Although there are many definitions of risk, it should be assumed that its complex character makes it impossible to formulate a universal concept which would be identical for all fields of knowledge. Additionally, risk in economic conditions is a common and objective phenomenon resulting from taking certain actions or restraining from them. It is justified that risk cannot be divided, in the strict sense of the word, since division means using various legal institutions which enable to assign to particular parties of the contract the necessity to bear the consequences of particular circumstances [Kulesza, Bitner, Kozłowska 2006, p. 167].

In PPP there are many risks which may threat a given undertaking. Their proper estimation consists in analysing the probability of occurrence and potential economic damage which they may cause. If both factors are significant, then the risk is regarded as high. If the risk is low, then also the probable damage is small.

\section{Risk management}

Risk management is a crucial issue for every organisation, both in the public as well as in the private sector. It may generally be assumed that risk management is a system which is to protect a given unit from negative consequences. It is compared to uncertain states management. These states may be defined as untypical phenomena or series of events which may occur. Risk management includes such actions as: planning, organising, coordination as well as control of implementers' work, material and information resources connected with active limitation of the causes and consequences of the phenomena which due to potential great losses or high probability of occurrence may pose a significant threat. The basic aim of risk management is to design the project in such a way that the risk level is acceptable by every participant and minimal to the whole project [www.nbp.pl/publikacje/materialy_i_studia/137. pdf (acces 7 August 2018.].

Additionally, risk management is a logical and systematic method which is to make context, identify, analyse, 
evaluate, act, supervise and inform about a risk in a manner which will enable an organisation to minimize losses and maximize possibilities [the Ministry of Finance].

Risk management in the case in the case of PPP is a task belonging to the public institution, which is the initiator, coordinator and due to managing public funds is obliged to take actions which are to spend public funds efficiently by, among others, placing the assets in such undertakings as PPP.

Risk management is seen as good management practice. The sole process of risk management includes the following stages:

- understanding performed activity,

- identification,

- analysis,

- scoring,

- risk prioritising,

- management.

Risk management cannot be treated as a burden to the organisation but as a way to maximize available possibilities and minimize the probability of failure.

It constitutes a basis for creating proper corporate governance, i.e. a combination of processes and structures introduced to achieve proper information flow, management, to direct and monitor actions in an undertaking targeted at achieving the objectives set. It is considered that risk management may help in enhancing the quality of services and using available possibilities. It may also actively facilitate managing operational and service activities as well as implementing changes. This process is a tool which leads to success [the Ministry of Finance].

\section{Management control}

Management control is a tool which PPP parties may use in the process of risk management. This institution was introduced into the legal system by the amendment to the Act on public finance of 27 August 2009 [Journal of Laws 2009 No 157, item 1240, later amended]. The legislator wanted to improve the management of a public sector unit. The introduction of management control was to gradually shift to the managerial governance model.

Here it needs to be emphasised that management control includes financial management of the public sector unit but it does not exclude covering other units in the scope of the tasks implementation, achieving goals set by a given public sector unit within specific undertakings in various legal forms. Such adopted model of management control allows to apply it in PPP and conduct procedures proper to management control on the level of partnership.

Management control proposed by the legislator is used to achieve expected results by implementing management system. In other words, it is a system which serves to collect and use information to evaluate organisation's effectiveness in correlation with the strategy set by it. It may be stated that it is active control [Matysek 2011, p. 39.].

Pursuant to Art. 68(2) APF the aim of management control is to ensure effectiveness and efficiency of the actions, reliability of statements, protection of resources, efficacy of the information flow and risk management. These aims comprise a closed catalogue. However, from the point of view of PPP, the scope of the aim which should be achieved may be shaped freely by PPP entities in the contract concluded between them.

Additionally, Art. 69 APF obliges the Minister of Finance to issue standards of management control and to publish them in the form of an announcement. These standards are to be guidelines for units' directors, in compliance with binding international control standards. They are presented below in five groups corresponding to particular elements of management control:

- internal environment, which concerns a unit management system and its organisation as a whole,

- risk management, which serves to increase the probability to achieve a unit goals by: determining aims and monitoring tasks implementation, risk identification, reaction to risk and preventive actions; it means focusing on identification and measurement of chances as well as threats, what should be reflected in creating strategic documents and units' action plans,

- control mechanisms which are the solution to specific risk which a given organisational unit wants to minimize by, e.g. systematic control, documentation, registering and approving specific economic operations, division of responsibilities, supervision within official hierarchy, recording exceptions from procedure, guidelines, instructions, etc., division of tasks enabling errors detection and correction,

- information and communication assuring that specific people from a unit have access to information necessary to fulfil their duties and at the same time ensuring proper information flow,

- monitoring and evaluating control system from the perspective of the effectiveness of the current 
control system and its particular elements, solving specific problems [Kaczurak-Kozak 2012, p.142]. Management control uses solutions which are applied to different management functions such as planning, organising and managing human resources by, among others: using norms established during the planning stage, managing people; giving feedback important or even essential for proper implementation of the management process in the scope covered by the planning processes [Przybyła 2003, p. 13].

Analysing management control it may be stated that it is based on the "3E principle":

- efficient (purposeful and effective),

- economical (beneficial, cost-effective),

- ethical (according to recognised values) [Kieżun 1998, p. 68].

Management control assumes that the result of a unit activity is possible to identify, compare, what as a result will allow a given unit to properly manage obtained resources and direct them to the spheres which are significant to achieve its goal [Winiarska 2012, p. 13].

It is a constant process of management actions which aim at achieving objectives set. Therefore, the starting point is to define these targets, which need to be common for all participants of a given process. In relation to PPP they must be proper for both public entity as well as for the private partner. The result of management control is to reach the targets set. Next step is to assess risks, i.e. identify them, measure their probability and results and finally to set priorities of preventive measures. When risks are established, then the scope of control is to be determined, whose basic aim is to prevent risk [Matysek 2011, p. 45]. Public administration should be guided by a basic assumption to create an environment in which risk identification will be done in connection with a process and control will be the answer to a specific risk [the Ministry of Finance].

Assuming that the control process took place with a frequency which guarantee a unit director obtaining current information about potential risks, corrective measures could be implemented naturally and in time allowing to achieve results, which based on feedback loop would bring expected results [Matysek 2011, p. 49].

\section{Conclusion}

To sum up, management control is an institution which allows to manage risk in public-private partnership. The aims defined in the closed catalogue, which is described in Art. 68(2) APF, may be shaped freely in PPP.

It needs to be emphasised that management control is applied to public sector units as well as to other units in the scope in which they use and manage public funds. This means that it may be used both in PPP implemented on national as well as local government level.

This institution is used to achieve results by implementing a management system which consists in collecting and using information to assess the effectiveness of an organisation in correlation with the strategy determined by it. It should be stated that Polish legal system allows public sector units to conduct the process such as management control, which as a system of effective risk management is a proper instrument which may be used by the PPP parties. Implementing management control procedures is a guarantee to achieve expected results.

\section{Bibliography}

Gajewski P. (2007), Organizacja procesowa, PWN, Warszawa. Kaczurak-Kozak M. (2012), Specyfika systemu kontroli zarzadczej na uczelni publicznej, "Finanse, Rynki Finansowe, Ubezpieczenia" no. 53.

Kieżun W. (1998), Sprawne zarzadzanie organizacjami, SGH, Warszawa.

Kulesza M., Bitner M., Kozłowska A. (2006), Ustawa o partnerstwie publiczno-prywatnym. Komentarz, WoltersKluwer Polska, Warszawa.

Kupsch P.U. (1975), Risiken als Gegenstand der Unternehmenspolitik, "Wirtschaft und Studium" no. 4.

Matysek M. (2011), Projektowanie modelu systemu kontroli zarządczej, "Kontrola Państwowa" no. 2.

Ministerstwo Finansów, Podręcznik wdrożenia systemu zarządzania ryzykiem $\mathrm{w}$ administracji publicznej w Polsce [online], www.mf.gov.pl/ documents/764034/3349878/20130307_3_zarzadzanie_ryzykiem_w_sektorze_publicznym.pdf, access as of 7 August 2018.

Petrozolin-Skawrońska B. (1998), Nowy leksykon PWN, PWN, Warszawa.

Przybyła M. (2003), Organizacja i zarządzanie. Podstawy wiedzy menedżerskiej, Akademia Ekonomiczna im. Oskara Langego, Wrocław.

Rowe W.D. (1977), An Anatomy of Risk, W. D. Rowe John Wiley\&Sons, New York.

Willet A.H. (1951), The Economic Theory of Risk Insurance, University of Pennsylvania Press, Philadelphia. 
Winiarska K. (2012), Pojęcie i klasyfikacja kontroli zarzadczej w literaturze zagranicznej, "Zeszyty Naukowe Uniwersytetu Szczecińskiego” no. 52.

Zarządzanie ryzykiem - ujęcie definicyjne [online], www.audytryzyka.com/index.php?inc $=14 \&$ id_ arty $=12867844420224$, access as of 7 August 2018.

Zarządzanie ryzykiem w project finance [online], www.nbp. pl/publikacje/materialy_i_studia/137.pdf, acces as of 7 August 2018.

\section{Legal Acts}

Act of 25 July 2005 on public-private partnership (Journal of Laws No. 169, item 1420).

Act of 19 December 2008 on public-private partnership (Journal of Laws of 2017, item 1834, later amended).
Act of 27 August 2009 on public finance (Journal of Laws of 2017, item 2077, later amended).

Regulation of the Minister of economy of 21 June 2006 on risks involved in projects carried out through public-private partnership (Journal of Laws No. 125, item 868).

\section{Author biography}

Krystian Jaszczyk - PhD student at the Department of Public Finance and Financial Law, Faculty of Law, University of Bialystok, Poland. The author's specialisation is public-private partnership. He is a member of the Center for Information and Research Organization in Public Finance and Tax Law of Central and Eastern Europe Countries. 